\title{
Penampilan Produksi Ternak Kambing Kacang Jantan dari Berbagai Kelompok Umur di Kecamatan Insana Utara Kabupataen Timor Tengah Utara
}

\author{
Maria Imelda Tmaneak ${ }^{a}$, Veronika Y. Beyleto ${ }^{b}$, Margaretha Nurwati $^{\mathrm{c}}$ \\ ${ }^{a}$ Fakultas Pertanian, Universitas Timor, Kefamenanu, TTU - NTT, 85613, Indonesia. \\ ${ }^{b}$ Fakultas Pertanian, Universitas Timor, Kefamenanu, TTU - NTT, 85613, Indonesia. \\ ${ }^{c}$ Fakultas Pertanian, Universitas Timor, Kefamenanu, TTU - NTT, 85613, Indonesia.
}

\section{Article Info}

Article history:

Received 17 Mei 2015

Received in revised form 2 Juni 2015

Accepted 1 Oktober 2015

\section{Keywords:}

Kambing Kacang

Jantan

\section{Abstrak}

Penelitian ini dilaksanakan di Kecamatan Insana Utara, Kabupaten Timor Tengah Utara sejak bulan Januari sampai Februari 2015 dengan tujuan untuk mengetahui penampilan produksi ternak ternak kambing jantan berbagai kelompok umur. Metode penelitian yang digunakan adalah metode survey dan pengukuran langsung untuk mendapatkan data primer. Sedangkan data sekunder diambil dari instansi terkait yang berhubungan dengan penelitian. Hasil penelitian penampilan produksi kambing Kacang jantan dari berbagai kelompok umur menunjukkan bobot badan kambing jantan dari berbagai kelompok umur yaitu anak, muda dan dewasa adalah 6,89 $\pm 2,52 ; 14,21 \pm 2,27$ dan $24,31 \pm 4,53$. Koefisien variasi 36,57\%; $15,97 \% ; 10,70 \%$. Tinggi pundak kambing kacang jantan dari berbagai kelompok umur anak, muda dan dewasa adalah $35,36 \pm 5,40 ; 44,95 \pm 3,33$ dan 52,98 $\pm 4,32$ dengan koefisien variasi $15,27 \% ; 7,40 \%$ dan $8,15 \%$. Panjang badan kambing kacang jantan dari berbagai kelompok umur adalah $31,53 \pm 6,17 ; 39,93 \pm 2,69$ dan 49,02 $\pm 4,81$ dengan koefisien variasi $19,54 \% ; 6,71 \%$; $9,81 \%$. Lingkar dada kambing kacang dari berbagai kelompok umur adalah 41,46 $\pm 6,64 ; 53,53 \pm 3,28$ dan $67,72 \pm 6,09$ dengan koefisien variasi $16,01 \% ; 6,17 \%$ dan $8,99 \%$. ๑2016 dipubikasikan oleh JAS

\section{Pendahuluan}

Ternak kambing merupakan ternak ruminansia kecil selain ternak domba. Ternak kambing adalah ternak serba guna yang menghasilkan daging, susu, kulit, bulu, dan kotoran dapat digunakan sebagai pupuk kandang yang berguna bagi tanaman karena mengandung unsur hara yang tinggi sehingga dapa memperbaiki struktur tanah. Ternak kambing juga cukup dikenal oleh masyarakat dan memegang peranan penting dalam perekonomian masyaraka pedesaan karena pada umumnya usaha pemeliharaan ternak kambing dilakukan di daerah pedesaan dan tidak dapat dipisahkan dari usaha tani di Indonesia.

Kambing Kacang merupakan bangsa kambing lokal Indonesia dengan cir tubuh relatif kecil, pemeliharaannya sangat sederhana dan memiliki daya adaptasi yang cukup tinggi terhadap alam setempat dan reproduksinya digolongkan sangat tinggi (Murtidjo, 1995). Kambing Kacang sangat digemari oleh masyarakat untuk diternakkan karena ukuran tubuhnya tidak terlalu besar perawatan mudah, cepat berkembang biak, jumlah anak perkelahiran sering lebih dari satu ekor, jarak antara kelahiran pendek dan pertumbuhan cepat (Sarwono, 2010).

Sifat produksi pada kambing jantan biasanya diutamakan karena mempunya keturunan lebih banyak dari pada ternak betina. Penampilan produksi ternak kambing Kacang jantan sangat penting, namun produktivitas kambing Kacang jantan masih sangat rendah pada usaha peternakan rakyat. Sistem beternak masih bersifat tradisional, sehingga populasi kambing kacang jantan sangat rendah. Untuk itu perlu dibudidayakan secara baik agar populasi semakin meningkat antara lain melalui usaha peningkatan kelahiran, penekanan jumlah kematian, pengendalian pemotongan disertai kebijakan pemerintah melalui penyebaran bibit ternak lokal.

Insana Utara merupakan salah satu daerah di Kabupaten Timor Tengah Utara (TTU) yang sangat potensial dengan usaha peternakan dan jumlah populasi ternak kambing cukup banyak yaitu 3.145, dibandingkan dengan kecamatan lainnya (BPS, 2013). Kambing Kacang jantan perlu dipertahankan keberadaannya karena kambing Kacang jantan memiliki beberapa sifat spesifik diantaranya pertumbuhannya sangat cepat, kualitas karkasnya sangat baik, tahan pada kondisi lingkungan tropis, tahan pada pakan jelek, serta mempunyai fertilitas yang tinggi (Murtidjo, 1995), dan cepat berkembang biak, modal yang dibutuhkan relatif kecil dan pemeliharaan sederhana (Sosromidjoyo,1980).

Insana Utara memiliki potensi untuk pengembangan kambing kacang, namun sejauh ini data produksi kambing Kacang, terutama kambing Kacang jantan belum diketahui secara pasti sehingga penelitian ini bertujuan untuk mengetahui penampilan produksi ternak kambing Kacang jantan dari berbaga kelompok umur di Kecamatan Insana Utara, Kabupaten TTU.

\section{Metode}

Penelitian dilaksanakan selama dua bulan yakni bulan Januari sampa Februari 2015 dengan cara pengukuran langsung dan pengisian quisioner untuk mengetahui gambaran umum peternakan di lokasi penelitian.

Metode yang digunakan untuk menentukan lokasi kecamatan adalah Purposive sampling dengan jumlah populasi ternak kambing jantan lokal yang terbanyak. Penentuan lokasi penelitian didasarkan atas beberapa kriteria antara lain desa yang memiliki populasi ternak kambing jantan lokal terbanyak sert dapat dijangkau, sehingga di peroleh tiga desa dari lima desa yang ada di kecamatan Insana Utara yaitu: Kelurahan Humusu C, Desa Humusu Oekolo dan Desa Oesoko. Peternak contoh diambil berdasarkan kriteria memiliki ternak kambing jantan sekurang-kurangnya empat ekor, pengalaman beternak 3-4 tahun sehingga terpilih 30 responden.

Variabel yang digunakan dalam penelitian adalah 1) Bobot badan dengan cara penimbangan berat badan setiap ekor ternak dengan timbangan $(\mathrm{kg}) ; 2$ ) Lingkar dada $(\mathrm{cm})$ yaitu diukur dari belakang bahu sampai bagian bawah di belakang kaki depan melingkar; 3) Tinggi pundak yakni diukur belakang bahu sampai teracak kaki depan (menyentuh tanah) menggunakan pita ukur $(\mathrm{cm})$
Panjang Badan yaitu jarak antara tepi depan sendi bahu dan tepi belakang tulang tapis dengan posisi kambing berdiri tegak, dengan menggunakan pita ukur $(\mathrm{cm})$

Prosedur penelitian meliputi 1) Persiapan alat pengukur dan timbangan; 2) Persiapan quisioner; 3 ) Wawancara dengan peternak; 4) Pengukuran langsung di lapangan. Data yang dikumpulkan, ditabulasi kemudian dianalisa secara deskriptif yang meliputi perhitungan nilai rata-rata $(\bar{x})$, standar deviasi (SD) dan koefesien variasi (KV) yang berpedoman pada petunjuk Sudjana (1984).

\section{Hasil dan Pembahasan}

Sistem pemeliharaan ternak dilakukan secara tradisional, sebagian besar masyarakat menyatakan bahwa ternak kambing dilepas di padang penggembalaan dan diikat pada malam hari. Hal ini mengakibatkan terbatasnya campur tangan peternak dalam sistem pemeliharaan yang hanya sebagai usaha sampingan. Muljana (1982) menyatakan bahwa kandang sangat penting bagi ternak kambing yaitu sebagai tempat bernaung dimalam hari, sebagai tempat berlindung dari panas matahari, hujan ataupun bila ada angin yang kencang Hasil penelitian menunjukan bahwa peternak di kecamatan Insana Utara memiliki kandang yang masih sederhana yang terbuat dari kayu, bambu dan bebak, yang beratap alang-alang daun gewang, dan letak kandang sebagian disamping rumah dan dibelakang rumah, lantai kandang umumnya terbuat dari tanah, ternak kambing yang dipelihara semuanya dikandangkan dalam satu kandang tanpa memperhatikan jenis kelamin dan kelompok umur ternak.

Makanan utama ternak kambing di kecamatan Insana Utara berupa rumputrumputan dan daun-daunan (daun lamtoro, daun turi) sebagai tambahan yang jumlahnya sangat tergantung pada alam. Sistem pemberian pakannya pada malam hari dan diberikan begitu saja pada kambing yang ada di dalam kandang.

Salah satu faktor penghambat pengembangan usaha peternakan adalah penyakit, karena ternak yang menderita penyakit akan menurun produktifitasnya. Hasil wawancara dengan responden diketahui bahwa penyakit yang sering menyerang ternak kambing di daerah penelitian adalah perut kembung dan penyakit kulit (scabies). Di lokasi penelitian cara mengatasi penyakit dengan daun "suf muti" dihancurkan kemudian digosokan pada bagian yang gatal atau luka tersebut, ada juga mengunakan obat-obatan dari petugas lapangan seperti Medoksin, Terramycin, Wormektin dan Ivomex.

Pendugaan usia kambing untuk ternak dalam pemeliharaan mempunyai peranan yang penting. Cara yang paling cepat untuk mengetahui umur ternak adalah dengan melihat catatan produksi atau dari kartu rekording ternak yang bersangkutan, serta berdasarkan gigi seri (Frandson,1993). Umur ternak kambing jantan di lokasi penelitian dari umur jantang anak 1-8 bulan, jantan muda 8-11 bulan dan jantan dewasa 12 bulan ke atas. Sesuai pendapat (Syamyono, 2014) menyatakan bahwa kelompok anak berumur 3-8 bulan, muda berumur $>8-12$ bulan dan kelompok umur jantan dewasa 13 bulan ke atas. Di lokasi penelitian umur ternak ditentukan melalui gigi, belum ada catatan untuk setiap ternak yang bertumbuh khususnya pada ternak kambing Kacang.

\subsection{Bobot Badan}

Bobot badan merupakan bobot yang didapatkan selama ternak dipelihara dan dalam keadaan hidup (Natasasmita, 1979).

Tabel 1. Rata-Rata, Standar Deviasi dan Koevisien Keragaman Bobot Badan.

\begin{tabular}{lrcc}
\hline Kel. Umur & $\bar{x}(\mathrm{~kg})$ & SD & KV $(\%)$ \\
\hline Anak & 6,89 & 2,52 & 36,57 \\
Muda & 14,21 & 2,27 & 15,97 \\
Dewasa & 24,31 & 4,53 & 10,70 \\
\hline
\end{tabular}

Rata-rata bobot badan kelompok umur anak, muda dan dewasa kambing Kacang jantan di Kecamatan Insana Utara berturut-turut adalah: 6,89 kg; 14,2 $\mathrm{kg}$ dan $24,31 \mathrm{~kg}$. Rata-rata bobot badan kambing kacang jantan dari ketiga kelompok umur tersebut lebih rendah dibandingkan dengan hasil penelitian 
Natasasmita (1979) dengan bobot badan anak, muda, dan dewasa berturut-turut adalah 8,$47 ; 18,16 ; 24,69$. Terlihat adanya perbedaan nilai rata-rata pada kedua hasil penelitian karena tatalaksana pemeliharaan di Insana Utara masih bersifat semi intensif, dan juga faktor pakan yang sangat terbatas dari sisi kualitas dan kuantitas. Menurut AAK (1983), faktor pakan sangat penting dalam pemenuhan kebutuhan pertumbuhan, kekurangan pakan merupakan suatu kendala besar dalam proses pertumbuhan. Hal ini menunjukan bahwa kualitas padang penggembalaan rendah sehingga, nutrisi tidak cukup untuk meningkatkan bobot badan. Rumput alam dipadang penggembalaan diduga mengandung kadar protein kasar rendah dan serat kasar yang tinggi sehingga pertumbuhan ternak kambing di Kecamatan Insana Utara menjadi rendah. Karena nutrisi yang dikonsumsi tidak mencukupi untuk pertumbuhan yang maksimal. Selain itu, faktor pendidikan formal dan non formal tentang cara beternak kambing yang dimiliki oleh peternak di lokasi penelitian masih sangat rendah sehingga berpengaruh terhadap penerapan manajemen pemeliharaan ternak kambing di wilayah tersebut.

Standar deviasi merupakan salah satu ukuran statistik yang digunakan untuk menjelaskan homogenitas kelompok (Boediono dan Koster, 2004). Standar deviasi berat badan kambing Kacang jantan kelompok umur anak, muda dan dewasa di lokasi penelitian berturut-turut adalah: 2,52; 2,27 dan 4,53. Standar deviasi bobot badan kambing Kacang jantan dewasa lebih besar dari kelompok umur muda dan anak. Kenyataan ini menunjukkan bahwa bobot badan kambing Kacang jantan dewasa memiliki variabilitas yang lebih tinggi dan data diantara anggota elemen heterogen. Hal ini di dukung oleh pendapat Walpole dan Myers (1995) yang menyatakan bahwa semakin tinggi deviasi standar, semakin besar penyimpangan data dari rata-rata hitungnya, sehingga dikatakan data memiliki variabilitas tinggi. Artinya, data diantara anggota elemen adalah heterogen.

Koefisien variasi merupakan ukuran dispersi relatif yang digunakan untuk membandingkan variasi dua atau lebih kelompok data. Koefisien variasi bobot badan kambing Kacang jantan kelompok umur anak, muda dan dewasa dalam penelitian ini adalah $36,57 \% ; 15,97 \%$ dan $10,70 \%$. Nilai koefisien variasi bobot badan terbaik di miliki oleh kambing jantan dewasa karena memiliki nilai koefisien variasi yang lebih kecil kambing jantan anak dan muda. Furgon (2004) menyatakan bahwa semakin kecil nilai koefisien variasi sebuah populasi menunjukkan kualitas sifat populasi yang lebih baik karena memiliki tingkat keragaman yang lebih rendah.

\subsection{Tinggi Pundak}

Tinggi pundak adalah jarak yang diperoleh dari titik tertinggi pundak secara tegak lurus sampai ke tanah. Pundak adalah titik tertinggi pada bagian hewan yang bertungkai empat, ini digunakan sebagai standar pengukuran tinggi hewan (Soenarjo,1998)

Tabel 2. Rata-Rata, Standar Deviasi dan Koevisien Keragaman Tinggi Pundak.

\begin{tabular}{lccc}
\hline Kel. Umur & $\bar{x}(\mathrm{~cm})$ & SD & KV $(\%)$ \\
\hline Anak & 35,36 & 5,40 & 15,27 \\
Muda & 44,95 & 3,33 & 7,40 \\
Dewasa & 52,98 & 4,32 & 8,15 \\
\hline
\end{tabular}

Rata-rata tinggi pundak kelompok umur anak, muda dan dewasa kambing Kacang jantan di Kecamatan Insana Utara berturut-turut adalah: 35,36 cm; 44,95 $\mathrm{cm}$ dan 52,98 cm. Rata-rata tinggi pundak kambing kacang jantan dari ketiga kelompok umur tersebut lebih rendah dibandingkan dengan hasil penelitian Pamungkas et al. (2009) dengan tinggi pundak anak, muda, dan dewasa adalah 35,$96 ; 45$ dan $55,7 \mathrm{~cm}$. Hal ini diduga disebabkan karena perbedaan lingkungan termasuk manejemen pemeliharaan.

Standar deviasi yaitu suatu ukuran yang menggambarkan tingkat penyebaran data dari nilai rata-rata. Standar deviasi tinggi pundak kambing Kacang jantan kelompok umur anak, muda dan dewasa dilokasi penelitian masing-masing adalah: 5,40;3,33 dan 4,32. Dari hasil penelitian standar deviasi pada anak lebih tinggi dari pada muda dan dewasa, hal ini disebabkan karena Semakin besar nilai deviasi masing-masing data yang diteliti dari rata-ratanya, maka nilai variannya juga semakin besar. Variasi tinggi pundak kelompok umur anak lebih besar dari kelompok umur muda dan dewasa.

Koefisein varians adalah perbandingan antara Standar deviasi dengan harga mean (rata-rata) yang dinyatakan dalam angka persentase $(\%)$. Koefisien variasi tinggi pundak kambing Kacang jantan kelompok umur anak, muda dan dewasa dalam penelitian ini adalah $15,27 \% ; 7,40 \%$ dan $8,15 \%$. Dari hasil penelitian ini keragaman tinggi pundak kambing kacang jantan muda lebih kecil dibandingkan dengan anak dan jantan. Hal ini menunjukan bahwa semakin kecil koefisien variannya maka data semakin seragam (homogen), sebaliknya semakin besar koefisien varians maka data semakin bervariasi (heterogen).

Ukuran linear tubuh juga dipengaruhi oleh faktor ketersediaan pakan dan tata laksana pemeliharaan. Anggorody (1984), bahwa keberhasilan suatu usaha peternakan selain ditentukan oleh faktor-faktor lain, juga sangat di tentukan oleh faktor makanan, yang berkualitas tinggi, dengan kuantitas yang cukup menunjang, maka produksi yang diinginkan dapat tercapai. Reksodirprojo (1985), menyatakan bahwa apabila rumput dicampur dengan hijauan legum dapat meningkatkan mutu pakan ternak kambing. Dengan demikian tingkat konsumsi pakan akan meningkat yang pada akhirnya dapat meningkatkan pertumbuhan ternak

\subsection{Panjang Badan}

Ukuran Panjang badan dapat dibedakan menjadi dua yaitu panjang badan absolut dan panjang badan relatif. Panjang badan absolut adalah jarak antara ujung samping tulang bahu sampai dengan tulang duduk dari seekor ternak. Sedangkan panjang relatif adalah proyeksi (garis datar) dari pada panjang absolut (Soenarjo,1998). Pengukuran yang dilakukan dalam penelitian adalah panjang badan absolut.

Tabel 3. Rata-Rata, Standar Deviasi dan Koevisien Keragaman Panjang Badan.

\begin{tabular}{lccc}
\hline Kel. Umur & $\bar{x}(\mathrm{~cm})$ & SD & KV $(\%)$ \\
\hline Anak & 31,58 & 6,17 & 19,54 \\
Muda & 39,93 & 2,68 & 6,71 \\
Dewasa & 49,02 & 4,81 & 9,81 \\
\hline
\end{tabular}

Rata-rata panjang badan kelompok umur anak, muda dan dewasa kambing Kacang jantan di Kecamatan Insana Utara berturut-turut adalah: 31,$53 ; 39,93$ dan 49,02 cm. Rata-rata panjang badan kambing kacang jantan dari ketiga kelompok umur tersebut lebih rendah dibandingkan dengan hasil penelitian Laha (1988) dengan tinggi pundak anak, muda dan dewasa adalah 31,94; 42,01 dan $51,42 \mathrm{~cm}$. Terlihat adanya perbedaan nilai rata-rata pada kedua hasil penelitian karena tatalaksana pemeliharaan di Insana Utara masih tradisional sehingga kurang terkontrol. Penambahan Panjang badan juga dipengaruh oleh fakor ketersediaan pakan yang berkualitas tinggi sehingga panjang badan yang ditampilkankan relatif bagus. Hal ini memberikan pengaruh yang positif terhadap panjang badan ternak kambing Kacang, karena pakan tetap memberikan pertambahan panjang badan yang lebih baik dari ternak yang tidak mendapatkan pakan yang kurang menunjang (Bili, 1998).

Standar deviasi adalah sebuah ukuran penyebaran yang menunjukan standar penyimpangan atau deviasi data terhadap nilai rata-ratanya. Standar deviasi panjang badan kambing Kacang jantan kelompok umur anak, muda dan dewasa dilokasi penelitian masing-masing adalah 6,$17 ; 2,68$ dan 4,81. Dari hasil penelitian ini standar deviasi anak lebih tinggi dari pada muda dan dewasa.

Koefisien variasi adalah perbandingan antara simpangan standar dengan nilai rata-rata yang dinyatakan dengan persentase. Koefisien variasi panjang badan kambing Kacang jantan kelompok umur anak, muda dan dewasa dalam penelitian ini adalah: $19,54 \% ; 6,71 \%$ dan $9,81 \%$. Dari hasil penelitian ini panjang badan kambing kacang jantan muda koefisien variasinya lebih kecil dibandingkan dengan anak dan dewasa. Koefisien variasi berguna untuk melihat sebaran data dari rata-rata hitungnya. Semakin kecil koefisien variasinya, maka data itu semakin homogen.

\subsection{Lingkar Dada}

Lingkar dada adalah salah satu indikator yang dapat digunakan untuk menentukan pertambahan bobot badan ternak. Lingkar dada diukur dari belakang sampai bagian bawah dibelakang kaki depan melingkar.

\begin{tabular}{cccc}
\multicolumn{4}{c}{ Tabel 4. Rata-Rata, Standar Deviasi dan Koevisien Keragaman Lingkar Dada. } \\
\hline Kel. Umur & $\bar{x}(\mathrm{~cm})$ & SD & KV $(\%)$ \\
\hline Anak & 41,46 & 6,64 & 16,01 \\
Muda & 53,53 & 3,28 & 6,17 \\
Dewasa & 67,72 & 6,09 & 8,99 \\
\hline
\end{tabular}

Rata-rata lingkar dada kelompok umur anak, muda dan dewasa kambing Kacang jantan di Kecamatan Insana Utara berturut-turut adalah: 41,46; 53,53 dan $67,72 \mathrm{~cm}$. Rata-rata lingkar dada kambing kacang jantan dari ketiga kelompok umur tersebut lebih rendah dibandingkan dengan hasil penelitian Laha (1988) dengan lingkar dada anak, muda, dan dewasa adalah 35,2; 61,07 dan $68,54 \mathrm{~cm}$. Terlihat adanya perbedaan nilai rata-rata pada kedua hasil penelitian diduga karena tatalaksana pemeliharaan di Insana Utara masih bersifat semi intensif, manejemen kurang memadai, dan juga faktor pakan.

Standar deviasi merupakan akar kuadrat positif dari variansi. Standar deviasi lingkar dada kambing Kacang jantan kelompok umur anak, muda dan dewasa dilokasi penelitian masing-masing adalah 6,64; 3,28 dan 6,09. Standar deviasi lingkar dada pada kambing kambing jantan anak lebih tinggi dari pada muda dan dewasa.

Koefisien variasi adalah perbandingan antara simpangan standar dengan nilai rata-rata yang dinyatakan dengan persentase. Koefisien variasi berguna untuk melihat sebaran data dari rata-rata hitungnya. Koefisien variasi lingkar dada kambing Kacang jantan kelompok umur anak, muda dan dewasa dalam penelitian ini adalah: $16,01 \% ; 6,17 \%$ dan $8,99 \%$. Dari hasil penelitian ini lingkar dada kambing kacang jantan muda koefisien variasinya lebih rendah dibandingkan dengan anak dan dewasa. Hal ini menunjukan bahwa koefisien variasi lingkar dada kambing kacang jantan muda lebih homogen atau seragam dari kelompok anak dan dewasa.

Devendra dan Burns (1970), menyatakan bahwa faktor lingkungan yang banyak mempengaruhi kondisi kambing terutama adalah faktor makanan, ternak kambing yang mendapat makanan yang baik akan lebih cepat dewasa tubuh jika dibandingkan kambing yang mendapat makanan yang kurang baik (kebutuhan bahan kering tidak terpenuhi). Ukuran lingkar dada dipengaruhi oleh faktor tatalaksana pemeliharaan dan ketersediaan pakan. Siregar (2008) mengemukakan bahwa apabila kebutuhan ternak akan zat-zat makanan diperoleh dari hijauan sebaiknya diberikan hijauan yang berkualitas tinggi karena hijauan 
tersebut dapat memberikan energi yang tinggi dan dapat meningkatkan produsi ternak.

\section{Simpulan}

a. Bobot badan kambing jantan dari berbagai kelompok umur yaitu anak, muda dan dewasa adalah $6,89 \pm 2,52 ; 14,21 \pm 2,27$ dan $24,31 \pm 4,53$. Koefisien variasi $36,57 \% ; 15,97 \% ; 10,70 \%$.

b. Tinggi pundak kambing kacang jantan dari berbagai kelompok umur anak, muda dan dewasa adalah $35,36 \pm 5,40 ; 44,95 \pm 3,33$ dan $52,98 \pm 4,32$ dengan koefisien variasi $15,27 \% ; 7,40 \%$ dan $8,15 \%$.

c. Panjang badan kambing kacang jantan dari berbagai kelompok umur adalah $31,53 \pm 6,17 ; 39,93 \pm 2,69$ dan $49,02 \pm 4,81$ dengan koefisien variasi $19,54 \%$; $6,71 \% ; 9,81 \%$.

d. Lingkar dada kambing kacang dari berbagai kelompok umur adalah $41,46 \pm 6,64 ; 53,53 \pm 3,28$ dan $67,72 \pm 6,09$ dengan koefisien variasi $16,01 \%$; $6,17 \%$ dan $8,99 \%$.

\section{Pustaka}

AAK. 1983. Hijauan Makanan Ternak. Kanisius. Yogyakarta.

Anggorodi, R. 1994. Ilmu Makanan Ternak Umum. PT. Gramedia, Jakarta.

Bili Y. D. ( 1998). Pengaruh pemberian buah semu jambu mente (Anacardium occidentale) Pada kambing lokal jantan dengan pakan dasar rumput alam kering terhadap pertambahan berat badan ukuran linear tubuh.Skripsi. Fapet Undana Kupang.

Boediono dan W. Koster. (2004). Teori dan Aplikasi Statistika dan ProbabilitasBandung: PT. Remaja Rosdakarya.

BPS TTU. 2013. Timor Tengah Utara Dalam Angka. BPS TTU. Kefamenanu.

Devendra C. dan M. Burns. 1994. Produksi Kambing di Daerah Tropis. Penerbit ITB, Bandung.

Frandson R. D. 1993. Anatomi dan Fisiologi Ternak Gadja Muda University Press. Yogyakarta.

Furqon. 2004. Statistika Terapan Untuk Penelitian.Bandung-AlfaBeta.

Muljana, W. 1982. Cara Beternak Kambing. Aneka Ilmu: Semarang.

Murtidjo. B. A. 1995. Beternak Kambing dan Domba.Kanisius. Jogjakarta.

Natasasmita. 1979. Pedoman Beternak Domba. Direktorat Peternakan Rakyat. Direktorat Peternakan Depertemen Pertanian. Jakarta

Reksohadiprodjo, S. 1985. Produksi Tanaman Hijauan Makanan Ternak Tropika. BPFE, Yogyakarta.

Pamungkas F. A., A. Batubara, M. Doloksaribu dan E. Sihite. 2009. Potensi Beberapa Plasma Nutfah Kambing Lokal Indonesia. Petunjuk Teknis. Pusat Penelitian dan Pengembangan Peternakan Badan Penelitian dan Pengembangan Pertanian Departemen Pertanian.

Sarwono B. 2010. Beternak Kambing Unggul. Penebar swadaya. Jakarta.

Siregar S. B. 2008. Penggemukan Ternak Kambing dan Domba. Penebar Swadaya Jakarta.

Soenarjo C.H. 1988. Buku Pedoman Kuliah Ilmu Tilik Ternak. CV. Baru, Jakarta. Sosroadmijojo 1980. Ternak Potong Kerja. CV. Yasaguna. Jakarta.

Sudjana.1984. Metode Statistika. Tarsito. Bandung.

Syamyono, O. D. Samsudewa, E. T. Setiatin. 2014. Korelasi Lingkar Skrotum dengan Bobot Badan, Volume Semen, Kualitas Semen, dan Kadar Testosterone Pada Kambing Kejobang Muda dan Dewasa.

Walpole R.E, dan Myers, R.H, (1995), Ilmu Peluang dan Statistika untuk Insinyur dan Ilmuwan, Edisi ke 4, Institut Teknologi Bandung 1995. 